\title{
Research on the strategies of English learners in the language practice base
}

\author{
Xiaohui Wang \\ Foreign Language School \\ North-East Dianli University, Jilin, China \\ wxhxuna@126.com
}

\begin{abstract}
English teaching process, language practice plays an important role in mastering language skills for language learners. Language practice base can help English learners to grasp English skills effectively when it is used as a learning platform. Its effectiveness lies in the fact that it can provide the learners with a nearly real language environment when they practise their oral English. Besides, it offers British and American pronunciation, so learners can imitate any of the two kinds as they like. At last, when the learners finish their writing prompts, they can receive instant comments which are realized by computer softwares automatically. Working hard, correcting errors constantly and practising again and again are good strategies for English learners to follow so as to make a rapid progress.
\end{abstract}

\section{Keywords-Base; Language practice; Strategies;}

\section{INTRODUCTION}

English learning can be implemented through various approaches. Many English learners study language and culture by way of self-study, classroom learning and language immersion process, etc. According to the experts and scholars in pedagogy, psychology and linguistics, language practice base is an effective platform which can promote English learners' language levels and enhance the speed of mastering a language. It is a problem worthy of studying how English learners choose their best strategies in language practice platform.

\section{THE RELATIONSHIP BETWEEN LANGUAGE TEACHING AND LANGUAGE PRACTICE BASE}

A blueprint called "National medium and long-term program for education reform and development" shows that it is a core task that higher education institutions should improve their qualities and it is also the basic requirement which a country with strong education calls for. [1] If a country is planning to improve its teaching quality, it is necessary to pay attention to the practice teaching links where the English language teaching activities can be spread through various means. Different scholars have different views on how to achieve better effects for language practice teaching. Looking through CNKI(Chinese academic national knowledge index), many experts and scholars are studying English practice teaching. These studies include English practice teaching mode, teaching practice of localization and globalization, business
English teaching and practice, etc. Most scholars have realized the importance of a language practice base and strengthened the relationship between language teaching and language practice base. Wei Sun believes that "establishing a solid business English off-campus practice base is a way to strengthening business English teaching practice and to reinforcing the training of students' business English professional skills" [2]. Lin Lan stresses that " various forms of practice should be carried out to enhance English teaching practice with the idea that students are the center, whose main purpose is to develop students practical English skills" [3]. Na Lv and Dong Ma indicate that" The local evolution and global adaptation of college English practice teaching are able to realize the mutual supplement and complement each other. Therefore, qualified personnel of cross-cultural communication can be created, who can use English freely. " [4] Shujun Ji argues that "It is very necessary to discuss the links of business English practice teaching in order to cultivate talents with applied techniques for the production and social practice " [5].

\section{THE DEFINITION AND FUNCTION OF LANGUAGE PRACTICE BASE}

What's the main purpose and function of language practice base? How can we define it? They are questions that are full of challenges. Access to relevant data, language practice base can be defined as some comprehensive training platforms or places where English learners can practise their English listening, English conversation, English reading, English writing and Chinese-English two-way translation techniques related to English practical skills. English is a foreign language, whose typical features lie in the fact that learners should not only learn English knowledge but they also should practise their skills. English knowledge can be gained through the way of classroom teaching or self-study, including English culture knowledge, English grammar, vocabulary, English phonetic knowledge, English listening, speaking, reading skills, translating and writing skills. English skills include oral English skills, listening skills, reading skills, writing and translating skills. It takes a long time for English learners to master English knowledge and acquire their English skills. Krashen's input hypothesis suggests English skills can be naturally output as long as the English learners get a great number of inputs. Later, when tested, part of krashen's theory is wrong. Most scholars believe that the language knowledge input is effective when it is comprehensible so that it can be 
mastered by the learners and the output of the English skills is not a natural process. At the same time, a Canada's famous scholar, Swain, draws a conclusion through some experiments - a large amount of direct input does not lead to automatic output of language skills; only through a lot of practice can the students' output of language skills be acquired. It is a significant question to discuss how to realize the transformation from the input of understandable materials to output of language competence. Experts and scholars generally argue that setting up the language practice base (practice platform) is a good way to solve this problem. From this perspective, the function of language practice base is providing students with certain facilities or places, whose purpose are that students can reap the best benefits of language practice at the cost of minimum effort.

\section{STRAGEGIES FOR ENGLISH LEARNERS TO IMPROVE THE LEARNING EFFICIENCY}

English language practice base is designed to improve students' English practical skills, thus selected English practice materials in base have very strong pertinence. The arrangement of the learning materials follows the rules of step-by-step and the content of learning materials covers widely. Listening material involves in different styles of the British English and American English pronunciation, which is helpful for learners to contact with the most authentic English pronunciation materials in western societies. The selection of reading materials is also closely related to the latest report of the most influential English journals in the world, where living use of English and the latest achievements of English culture are introduced. The selection of writing materials is closely linked to the most influential tests in the world such as British IELTS, American TOEFL, Chinese CET4 or CET6 and Chinese EMT4 or EMT8. As a result, it has great pertinence and practicability for learners to train their writing skills. Oral English materials and software can realize the man-machine dialogue and can achieve real British English and American English pronunciation as well as the function of real-time error correction, which has a great help to the spoken English training process. Besides, it can achieve an almost real language communication environment, which is the Gospel for learners whose mother tongue is not English. Since the function of language practice base is so strong, how to make the most use of language practice base is a studying problem worthwhile.

For oral English learning, learners can study English from basic stage, or from an intermediate level, or from senior level according to their own current needs. No matter what stage they want to begin, it is learners' priorities in which they can achieve as much language learning environment as possible. For starters, more imitations and memorizations are the efficient way to finish the basis of English language learning reserves. Level of spoken English can be measured by many ways including accurate English pronunciation, the accurate employment of situational words, clear explanation of one's thoughts and the appropriate use of grammar, vocabulary and syntax, etc. Many students misunderstand that fluency is the standard to measure one's oral English level. As a matter of fact, it should be a criterion to judge learners oral English level that he/she understands accurately the other speaker's words and expresses his/her own idea clearly and concisely.

Most learners feel difficult to grasp listening skills. How language learners improve the learners' listening competence rapidly by practising in language practice base is a problem that each English learner has to face and solve. In recent years, the requirement for English learners is improving both domestically and overseas. The range of English listening materials is very wide and involving every aspect of life, such as TOEFL in America. Not only scope of listening materials is broad but it also requires the listening materials in details. Besides, the demand of understanding language and cultural knowledge is improving. Especially the content of the listening materials will involve in the easy part of Academic English and English of Science. Based on the above characteristics, the density of listening practice should be increased by the English learners. According to the American scholars' investigation the words associated with daily English must be heard over 8-10 times before it can be understood completely. Therefore, the improvement of English listening results from a lot of English listening materials input. English learners can begin from listening to special English of VOA and gradually get familiar with American culture, thinking and the characteristics of English. At last, they can be accustomed to Standard English of VOA and BBC. Practice makes perfect. It is the key for English learners to improve English listening comprehension that they often listen to English radio and or watch English TV programs.

For the cultivation of English reading and writing skills, Chinese students are better at reading skills, so it's no need to talk more; while the writing skills of Chinese students are generally weak, so it will be paid more attention to in this paper. For the cultivation of writing skills, the most important thing is to write by using the real-time correction software of language practice base. For a certain set topic composition, English learners must finish it within the prescribed period of time and immediate comment and revision can be made instantly, which can make English learners understand the strengths and weaknesses of his own composition so that it can be revised immediately. No matter how good a software or correcting means is, there is no guarantee that learners can efficiently improve writing skills. The most important thing is that learners are of a lot of practice. Practice tells us that English learners' writing skills will be greatly improved by writing around a 300 words composition every day and sticking to it a year or so, which can basically make the learner qualified for meeting the requirements of American TOEFL or British IELTS.

\section{SUMMARY}

English language practice base is especially set up for cultivating learners' language competence, so it can make English learners improve their English skills efficiently. According to their own level and learning characteristics, through convenient use of language practice bases and hard working learners skills can be effectively improved in such aspects as listening, speaking, reading, translating and writing. On the one hand, it depends on the learners' learning strategies to improve the efficiency of their English skills; on the other 
hand, it is due to the extent of English learners' subjective efforts. English learners can master the English skills efficiently by choosing appropriate method of study, using advanced language practice base facilities and spending great efforts.

\section{ACKNOWLEDGMENT}

Thank Sarah Detrich (an assistant professor of Salem State University of America) for her guidance and help.

\section{REFERENCES}

[1] National Medium and Long-term Plan for Education Reform and Development ( 2010-2020), [M] ,People's Publishing House, pp. 121-122, May 2010.

[2] Wei Sun, "Teaching Mode of Business English Practice for students in higher vocational institutions," Journal of Higher Vocational Institutions of Liaoning, vol. 12, pp. 055-057, Feburary 2010.

[3] Lan Lin, "The Build-up of Teaching mode in English Teaching Practice," Journal of Hunan Radio and Television University, vol. 03, pp 020-022, September 2006

[4] Na Lv,Dong Ma, "localization and globalization of Practice teaching-the domestic development of the college English teaching and its global adaptation," Heilongjiang Researches on Higher Education, vol. 06, pp. 165-167, June 2014.

[5] Shujun Ji, "Business English practical teaching issues and the construction of business English practice teaching system," Journal of sun yat-sen university review, vol. 25, pp. 201-204, Feburary 2005.. 